\title{
Phenomenon of aggressiveness in psychology, psychiatry and social life
}

\author{
Prof. Mikhail Reshetnikov, MD \& PhD, \\ East-European Psychoanalytic Institute - Rector (St.-Petersburg), \\ European Confederation of Psychoanalytic Psychotherapy (RF) - President, \\ Sigmund Freud University - Honorary Professor (Vienna, Austria) \\ SUMMARY
}

In this paper, psychological theories and hypotheses explaining possible mechanisms of aggressive behaviour, as well as social and psychological factors facilitating it, are reviewed. Connections between aggressive drive and individual's motivation, aspirations and psychopathological complexes, as well as influence of contemporary societal crises, are analysed. Manifestations of aggressive symbolism in contemporary arts, theatre and mass media are outlined.

Key words: aggression, behaviour, crime, mass executions, democratism, terrorism.

In the recent decade, professionals and the public have been interested in the topic of individual and interethnic tolerance. However, this formulation shifts the focus from the real problem, which is the growth of intolerance and various manifestations of seemingly ungrounded and unexplainable aggressivity. These range from common fights between individuals to abhorring interethnic conflicts and mass shootings of schoolchildren, co-workers and other innocent people. The problem of understanding seems to be connected to traditionally rational approach to psychopathological phenomena, which are difficult or even impossible to interpret without referring to irrational or unconscious factors, which Russian academic psychology has neglected for many decades.

Historically, the topic of human aggressivity was for the first time presented as a scientific problem at the I Psychoanalytic Congress in Salzburg on April 27, 1908 (4). Despite the fact that presenters focused on very different topics, all presentations were dealing with the issues of aggression. Sigmund Freud presented a paper called Casuistry (9), which was later published as Notes upon a Case of Obsessional Neurosis and became well known as the case of the Rat Man (10). In his presentation, Freud draws attention to "chronic coexistence of love and hatred towards the same person". Obsessive ideas, according to him, result from exaggerated tenderness on the one hand and unconscious sadistic hatred on the other.

Ernest Jones in his presentation Rationalization in the Everyday Life (3), emphasized the importance of Freud's ideas and spoke about motives that stay out of awareness and about the fact that rational explanations of human behaviour are far from its true reasons and cannot lead to understanding of its real motives.

Alfred Adler in his presentation Aggressive Drive in Life and in Neurosis (1) explained aggression as a drive aimed at struggling for pleasure in a hostile environment and depicts fear as one of the stages of this aggressive striving. Let us stress this idea: fear is one of the stages of aggressive striving. It should be mentioned that Adler's paper, despite some outdated concepts that it contains, is the most interesting and relevant even in our days. Considering the fact that 
Adler is known predominantly as the author who coined the term "inferiority complex", it makes sense to discuss his ideas in detail below.

In his presentation, Adler stresses that a crucial factor in an individual's life is his attitude to goals which he chooses for himself, or with which he is confronted by his life. Adler states that there is always something "attacking" in one's attitude to his goals, although it might be typical not for any individual and any type of his goal. Generally speaking, individual's reaction to his goals can be rather passive or even defensive, but Adler clarifies that his aim is to study specifically the aggressive drive, which is the basis of cruelty, striving for power and sadism. Let us notice the fact that Adler lists cruelty and sadism together with striving for power; their similarity is confirmed by many misanthropic regimes in the XX century, from Hitler's und Stalin's to more recent dictatorships of Ceausescu, Milosevic, Saddam Hussein etc.

Adler maintains that human drives, when enacted, are culturally transformed and become more sophisticated and differentiated. He mentions the possibilities for the aggressive drive to be sublimated and to turned into its opposite: greed can turn into generosity, tenderness into sadism, love into hatred. Examples of this latter version of transformation were abundant on the post-Soviet space and expressed in interethnic conflict as soon as the fear was gone (let us remember that fear is the first stage of aggressive drive).

Implementation of the aggressive drive, according to Adler, is related to one's orientation to one's own highly valued personality, and the drive intensifies whenever one's ambition or vanity is not satisfied. Therefore, aggressivity is typical for individuals suffering from excessive ambition or conceit.

Generally speaking, it can be viewed as one's striving exclusively towards one's own (sometimes, extremely perverted) goals and ideals with insufficient or totally lacking connection to external world, which is aggravated by excessive selfishness and undeveloped attachment. It is well known that the family is in crisis now, but the family is a system, in which attachments are initially developed. The next important parental structures are the society and the state, and we do not need to prove that these structures are also surviving a crisis.

As any other drives, aggressive drive is related to pleasure when fulfilled and to displeasure when it meets any obstacles. Elsewhere, I have already mentioned a phrase by my French colleague Dr. Alain Gibeault that if individuals contemplating a crime first come to us (psychologists or psychotherapists), the crime rate will decrease significantly. Unfortunately, it is just a good wish. Aggressive drive is so strong and governed by the pleasure principle, that only few intellectuals can make it a subject of psychotherapeutic study instead of acting it out in criminal behaviour. I have already described such rare cases of correction of aggressive drive (7), but these exception from the rule are exceedingly rare comparison to real aggressive and criminal actions. The key feature common for these intellectuals, who came for psychological help, was that they felt uncomfortable because of their condition and their awareness of their drives. Those who enact their aggressive drive are of primitive personalities and do not feel any discomfort in this connection. Just the opposite, they enjoy acting on their aggression, as well as planning and anticipating such actions and fantasizing about their imaginary power. In totalitarian societies, such drives and fantasies of power are almost completely psychologically suppressed by a system of repressive ideology and political control over people's behaviour. However, in transitional and crisis periods of society, some subjects with primitive pathological personality structure have completely different motivations. Later, we will turn to some specific examples from contemporary reality. 
In this paper, Adler explains that individuals who are prone to aggressiveness would often choose, without being aware of it, professions that allow them to fulfil their pathological drives in acceptable way. Some might feel offended, but our Western colleagues usually include jobs at slaughterhouse, police and school in this list. We will not analyse the former group here, but episodes of sadistic behaviour in two latter professions are abundant and well known.

Based on the concept of inferiority complex, which he introduced, Adler gives arguments related to organ systems, which do not sound convincing from contemporary perspective; however, he also formulates a number of interesting and relevant ideas. He speaks about general and partial inferiority, that is, inferiority of an organ, and maintains that "an inferior eye would have stronger striving to see, an inferior stomach would have a stronger wish for food and drinks, an inferior sexual organ would have an increased sexual desire". As I have seen materials of psychological and psychiatric expertise of a few serial rapists, I can add that this pathological drive is not only stronger but also more perverted, and the majority of rapists and paedophiles suffer from various sexual disfunctions.

We need to widen the list of phenomena described by Adler and expand it to the area of human psyche, which seems so vague for a non-professional. In particular, I dare suggest that in case of narcissistic personality, an inferior intellect would claim his misanthropic ideas to be brilliant; and inferior ethical attitude would claim to possess an outstanding aesthetical ability. Examples of this kind of "sophisticated aesthetics" are abundant in contemporary arts. In the end of this paper, I will give examples of such attempts to draw public attention to one's rather primitive personality and spread one's similarly primitive ideas. First of all, we should mention such a phenomenon as aesthetics of evil, which becomes more and more popular and socially acceptable. I have already analysed this topic in my paper On Spiritual Dimension of the Evil and concluded that aesthethisation of the evil makes it most dangerous. It is facilitated by the fact that the Internet can be used for popularization of any ideas by any people, including most severely disturbed ones. These people often show unusually high ability to culturally transform their primitive misanthropic ideas which in result might seem more sophisticated. However strongly we hate Nazism, its aesthetics could be called outstanding, and prominent European intellectuals participated in creating it. This fact should remind us of intellectuals' responsibility in the face of history.

Contemporary reality is characterized by distortion of democratic ideas and their transformation into democratism (the term is mine); also, there are fewer cultural prohibitions to hatred-laden information and propaganda of various human vices. Even for the academic community it is hard to accept the idea that people have not only elevated but also lower needs and desires, which should never be satisfied even in a virtual reality.

It is possible, I think, to formulate the following idea, which has received multiple confirmations in our age of informational outburst: human vices which are widely propagated by media as a form of virtual information then will inevitably transform into real phenomena, similarly widely spread.

Analysis of aggression in Adler's works is rather general and abstract, but in the light of contemporary tendencies, it is noteworthy that he mentions religious, interethnic and interracial conflicts and refers to a statement by outstanding German writer and philosopher Georg Lichtenberg: "It is amazing how reluctant people are to live up to their religious tenets and how eager they are to fight for them". It is important to address one of the main differences between human and animal aggression which Erich Fromm discusses in his work Anatomy of 
Human Destructiveness (11). Humans are endowed with imagination and can react aggressively to imaginary danger; it is only human being who can become aggressive due to "brainwashing". In social (herd) animals, aggression is aimed at establishing a hierarchy or, metaphorically speaking, a "social order". There are many parallels with human society. However, animal hierarchy is established via open fight, and the winner does not need to be more aggressive or smarter, but simply stronger. We might doubt intellectual abilities of animals, but we can see that the winner is immediately recognized by the whole herd or pride. It is not hatred and aggression in human version. There is something similar to it in apes: a dominant male would mistreat subdominant males, and these, being unable to fight him back, would replace their anger to those who have lower position in hierarchy. The lowest ranking males cannot ventilate their aggression, and it gets accumulated. Thus, a social pyramid is formed, and animals on its bottom cannot oppose others and are the last to get all goods, such as space, food and females (some lower ranking males are excluded from procreation). The main function of hierarchy is preservation of the species: it structures the "society" and propels endless struggle between its members. Fighting for females also has a biologically important function: the right to reproduce themselves is obtained by the strongest males.

In addition to these general biological laws, in human society such factors as self-respect, dignity and recognition by others are very important. In contrast to animals, unventilated aggression of lower ranking humans not only accumulates but also, in the absence of an outlet, can lead to a seemingly unreasonable outburst or will be redirected towards replacing objects. It is the nature of well know acts of vandalism on cemeteries, broken windows, burnt cars, shot classmates or co-workers.

In the end of his paper, Adler postulates that aggressive drive dominates any human activity. Let me remind you that this idea was formulated in 1908, when aggressive behaviour was universally considered pathological and culturally disapproved. I am not going to refer to the history of the XXth century, with its multiple examples of epidemic aggression. Let me just mention that contemporary perspective on aggression is qualitatively different: controlled aggression is viewed not only as acceptable but also as a positive factor, and a low level of social aggressiveness is perceived as a kind of shortcoming (which is reflected in jokes about Finish or Estonian all-too-calm men).

In this paper, Adler also states that aggressive drive fuels cruel images in arts, in which reality becomes pervaded with fears, compulsive ideas and hallucinations and indistinguishable from them. I do not need to remind you that contemporary cinema, in most cases, present more and more abhorring images of aggression and cruelty. Adler emphasizes that typical manifestations of aggression include admiring tyrants, such as Napoleon or Stalin, and being interested in events related to death, tragedies, illnesses and fears, which have become the main content of news broadcasts and pervade the contemporary informational space.

Finally, the individual's relationships with external world are destroyed, as well as feeling of belonging and attachment in interpersonal relationships. In the result, the individual becomes afraid of other people, of love and marriage, and develops what Adler calls "secondary attachments" to money and "eccentricities". Contemporary reality supports this hypothesis with abundant examples. There is no doubt that financial achievement is a measure of success in our society. Eccentricities are discussed less frequently. Let us, though, take a professional look at most TV shows related to entertainment and humour, will they not remind us what previously was considered symptoms of hebephrenia? 
In his work Vicissitudes of Drives, Freud (8) says, while speaking about the erotic drive, that transformations of drives include turning into the opposite, turning against the self, repression and sublimation. The external world as an object is undoubtfully perceived by most individuals as more and more hostile; the pleasure principle persists, albeit often in a perverted form (not in sexual meaning of the word); the notion of "active" in contemporary culture has gradually transformed into "aggressive", and we have to agree with Freud that drives, which are based on Eros and love and for thousand years used to be a basis for social feelings, can "turn into their opposite". Thus, it is quite realistic that hatred and death drive will come in place of love and liveliness. These novel social feelings and identifications have not been thoroughly reflected upon yet, but it is obvious that ideas of catastrophism, as a vivid equivalent or symbolic representation of the death drive, are widely spread.

It is well known that Freud disliked Steckel for his very original ideas, often contradicting his own. However, in 1913, while exploring the roots of moral, Freud admitted that Steckel's hypothesis of hatred as a basis of human relationships might be correct. In this case, the moral becomes a social mechanism of protection against annoying ethical prohibitions. Metaphorically speaking, Thanatos replaces Eros. Could it be that this transformation is the basis of "childfree" movement, which becomes more and more popular in the world?

In conclusion, let us consider a few examples from contemporary reality. Initially, the topic of increased aggression in the contemporary society attracted my attention in relation to the problem of Muslim terrorism. But I felt that the adjective "Muslim" disguises the problem instead of helping us to understand it. In 2004, I drew attention to "non-Muslim and international" terrorism $(5,6)$. At that time, my definition was severely criticized, as well as my prognosis of "palestinisation of Europe". Then I tried to draw attention to this problem after Andreas Breivik's FIND terrorist attack on his compatriots in Norway, the US shootings of compatriots of perpetrators and the shooting in Moscow, when Dmitry Vinogradov massacred his co-workers. It shows that we are dealing with qualitatively new manifestations of human aggression, which have not been properly studied yet.

Considering the lack of social and political demand for thorough analysis of this problem, it would have been possible to avoid speaking about this widely neglected topic, if more than 20 thousand of posts in support of Vinogradov had not appeared on the Russian Internet. Some of the authors expressed sincere admiration of his actions and voiced their intention to follow his example. There could be many explanations to this identification with the aggressor, and a deeper research of this problem is vitally important.

James Fox, a professor at the North Eastern University in Boston, the USA, says in his interview to Rossijskaya Gazeta (15.12.2012): "In American society, there are some people who are angry at the whole world and disappointed by it; they think that their life is ruined and do not want to live anymore. They lack emotional support from their families and friends. And they decide to make cruel revenge upon those who they consider responsible for their misfortunes and their problems in life. They choose between suicide and massacre, and they would decide to commit both". There is abundant evidence that this situation is typical not only for the USA.

Some experts maintain that the root of aggression is the self-preservation instinct and need for self-realization. However, considering the suicide ratio among such criminals, we can hardly think that they are driven by self-preservation. However, it is noteworthy that the individual's self-realization is related not only to his abilities but also to the level of his aggressivity. When one does not have enough abilities for a proper self-realization in his profession, love, family or business, he might turn to pathological self-realization via massacre and transient popularity 
that it brings. Who would read 1500 pages of Breivik's declaration of his rather primitive ideas on reforming the world if he had not shot dead 69 of his compatriots?

With the exception of works by Alfred Adler and Erich Fromm, research on this topic is very scarce in scientific literature. Monography by L. Berkowitz (2001) is also worth mentioning, especially his ideas on free sale of guns: "Guns do not only make violence possible but also facilitate it. The finger pulls the trigger, but the trigger can also pull the finger" (2).

In developed countries, despite qualitative and quantitative growth of law reinforcement structures and their technical equipment, the level of crime continues to increase. According to information that Russian Duma issued in 2012, sexual crime towards minors raised 30 times in the 7 years in Russia, therefore the legislation in this area was renewed. I dare say, however, that attempts to resolve the society's psychological and psychosocial problems by law enforcement methods will be no more successful than using police force against cancer or heart stroke. Psychiatrists and psychologists usually participate in studying aggressive actions only after a crime has been committed, that is, they study these specific cases as experts, although this problem should be studied as a general scientific problem.

Despite our understandably negative attitude to aggressive and mentally instable individuals, we need to admit that they are vulnerable, sensitive and psychologically "thin-skinned". The world has become more unjust and more aggressive, social and financial differentiation has increased in outrageous proportion. In any country, there are some people who are "more equal" than others, and the latter are potential, if not real, victims of the former. Therefore, those who do not want to identify with the victim, might choose to identify with the aggressor in naïve belief that "if I am the aggressor, others cannot be aggressive towards me". It is not a psychological but rather an acute socio-political problem. The mankind has been progressing towards humanistic attitude to individual and just socio-economic relationships: slavery was replaced by feudalism, and the feudal monarchy by capitalist democracy. Decline of the latter coincided with the informational epoch, when owners of all media have the goal of brainwashing us into belief this is the highest stage of human development. I doubt it, though. The change is inevitable. The fuel protests in France were just the first sign of it, like the storming of the Bastille in its time, which was a prison for nobility with only two prisoners hold there at that moment and seemed to be no obstacle for anyone. Just one more warning, I am afraid that this change will be very painful and uncivilized. Let me remind you the words signifying the fall of the European monarchy and the rise of democratic change: "I forgive all those who are to the cause of my death" (the last words of Louis XVI before he was beheaded by guillotine).

\section{References}

Adler A. Vlechenie k agressii v jizni i v nevroze// V kn.: Otchet o pervom chastnom psichoanaliticheskom sobranii v Zaltsburge 27 aprelja 1908 goda (tekst). / Sost. I ref. Otto Rank/ Per. s nem. - Izhevsk: ERGO, 2011. -S. 27-28. In Russian.

Adler A. Aggressive drive in life and in neurosis // In: Report on the first private psychoanalytic meeting in Salzburg on April 27, 1908 (text). / Ed. Otto Rank / Transl. from German. - Izhevsk: ERGO, 2011. -pp. 27-28.

Berkovits L. Agressiya: prichinyi, posledstviya i kontrol. / Per. s angl. - M.: Evroznak, 2001. - 512 S. In Russian.

Berkowitz L. Aggression: causes, consequences and control. / Transl. from English - Moscow: Euroznak, 2001. 512 pp.

Jones E. Ratsionalizatsiya v povsednevnoy zhizni. // V kn.: Otchet o pervom chastnom psihoanaliticheskom sobranii v Zaltsburge 27 aprelja 1908 goda (tekst). / Sost. i ref. Otto Rank / Per. s nem. - Izhevsk: ERGO, 2011. -S. 19. In Russian. 
Jones E. Rationalization in the everyday life. //In: Report on the first private psychoanalytical meeting in Salzburg on April 27, 1908 (text). / Ed. Otto Runk / Transl. from German. - Izhevsk: ERGO, 2011. - p. 19.

Otchet o pervom chastnom psihoanaliticheskoy sobranii v Zaltsburge 27 aprelja 1908 goda (tekst). / Sost. i ref. Otto Rank / Per. s nem. - Izhevsk: ERGO, 2011. - 40 S. In Russian.

Report on the first private psychoanalytical meeting in Salzburg, April 27, 1908 (text). / Ed. Otto Rank / Transl. from German. - Izhevsk: ERGO, 2011. - - 40 pp.

Psihologiya i psihopatologiya terrorizma. Gumanitarnyie strategii antiterrora. // Sbornik materialov mezhdunarodnoy konferentsii pod red. M. M. Reshetnikova. - SPb.: VEIP, 2004. - 312 s. In Russian.

Psychology and psychopathology of terrorism. Humanitarian strategies of anti-terror. // Proceedings of the international conference, ed. by M.M. Reshetnikov. - St. Petersburg: VEIP, 2004. - 312 pp.

Reshetnikov M. Fighting Terrorism by Exterminating Terrorists is Like Scooping the Flood with a Spoon. - Journal of Social Sciences, 2017. Vol. 3. Issue 2: 108-112.

Reshetnikov M.M. Mest i nenavist v terapevticheskom protsesse. V kn. Reshetnikov M.M. Trudnosti i tipichnyie oshibki nachala terapii. - SPb.: VEIP, 2009. - S. 183 - 197. In Russian.

Reshetnikov M.M. Revenge and hatred in the therapeutic process. In: Reshetnikov M.M. Difficulties and typical mistakes of the beginners. - St. Petersburg: VEIP, 2009. - pp. 183 - 197.

Freud S. Vlecheniya i ih sudba. // Z.Freyd. Sobr. soch. v 10 tomah. T. 3. Psihologiya bessoznatelnogo. Pod red. A.M. Bokovikova i S.I. Dubinskoy. - M.: 000 «Firma STD», 2006. - S. 79 -111. In Russian.

Freud S. Vicissditudes of drives // Collected papers, 10 volumes. V. 3. Psychology of the unconscious. Ed. by A.M. Bokovikov and S.I. Dubinskaya - M.: LLC "Firma STD ", 2006. - pp. 79 -111.

Freud S. Kazuisticheskoe // V kn.: Otchet o pervom chastnom psihoanaliticheskom sobranii v Zaltsburge 27 aprelja 1908 goda (tekst). / Sost. i ref. Otto Rank / Per. s nem. - Izhevsk: ERGO, 2011. - S. 17-18. In Russian.

Freud S. On Casuistic //In: Report on the first private psychoanalytic meeting in Salzburg on April 27, 1908 (text). / Ed. by Otto Rank / Transl. from German. - Izhevsk: ERGO, 2011. - pp. 17-18.

Freud S. Sobr. soch. v 26 tomah. T. 4. Navyazchivyie sostoyaniya. Chelovek-krisa. Chelovek volk. / Per. s nem. S. Pankova. - SPb.: Vostochno-Evropeyskiy Institut Psihoanaliza, 2007. - 320 s. In Russian.

Freud S. Collected works, 26 volumes. Volume 4. Obsessive states. Rat Man. Wolf Man / Transl. from German S. Pankov. - St. Petersburg: East European Institute of Psychoanalysis, 2007. - 320 pp.

Fromm E. Anatomiya chelovecheskoy destruktivnosti / Per. s angl. P.S.Gurevicha. - M.: AST, 2007. - 624 s. In Russian.

Fromm E. Anatomy of Human Destructivity / Transl. from English P.S. Gurevich. - Moscow: AST, 2007. - 624 pp. 